\title{
Intervention of Corporate Social Responsibility between Financial Effectiveness and Corporate Governance
}

\author{
Quang Linh Huynh \\ Tra Vinh University, Vietnam; huynhquanglinh@tvu.edu.vn
}

\begin{abstract}
Objectives: Socially responsible activities of firms play an imperative part in enhancing financial effectiveness and specially serve as an important mediator into the causal association between financial effectiveness and corporate governance. Therefore, the aim of the current project is to assess the association between financial effectiveness and corporate governance and then analyze the mediating function that corporate social responsibility takes in the causal relation of financial effectiveness with corporate governance. Methods/Statistical Analysis: To investigate the causal linkages from the components of corporate governance to financial effectiveness, OLS regression analyses were employed to test statistical significance. To examine statistically the mediating effect of corporate social responsibility, this research applied the procedures suggested ${ }^{1}$. Findings: The empirical results indicated that, good corporate governance is an important force leading to improved financial effectiveness, where managerial independence, ownership concentration and chief executive officer - chairperson duality are positively related to financial effectiveness. In addition, socially responsible activities of firms were evidenced as an important mediating factor affecting the relation of financial effectiveness with corporate governance. Socially responsible activities fully interfere with the effect of ownership concentration in the managerial board on financial effectiveness. In contrast, they just partially mediate the influences of managerial independence and chief executive officer - chairperson duality on financial effectiveness. Application/Improvements: This research offer researchers of management as well as business directors with a more comprehensive understanding on the complicated associations among financial effectiveness, corporate social responsibility and corporate governance. These will help executive officers to be more socially responsible and to decide on more appropriate corporate governance practices, which could improve financial effectiveness.
\end{abstract}

Keywords: Corporate Governance, Financial Effectiveness, Social Responsibility, Vietnam

\section{Introduction}

The impacts of business activities on our society have been increasingly acknowledged; there are hence growing concerns on corporate socially responsible behaviors of firms 2 . Related stakeholders of firms expect the firm's business activities including not only the quality and price of services or products, but also the protection for consumers, suppliers, workers and environments as well as other socially responsible activities. It is difficult for the firm to maximize its earnings that is the main goal of a firm, while pursues socially responsible activities concurrently. Nevertheless, following the standpoint of $\stackrel{3}{ }$, corporate social responsibilities make up a firm's resource, which could enable companies to build up intangible assets regarded as the causation of organizational competitive advantages.

This work enlarges the research of $=$, where the linkages among financial effectiveness, corporate social responsibility and corporate governance are supposed to be intricate. The empirical results of that research reveal the influence of socially responsible activities of firms on financial effectiveness is positive, between which corporate governance can moderate. Corporate governance refers to the managerial arrangement for controlling self-interest behavior of executives derived from the conflict in 
interests between different stakeholders ${ }^{4}$. The imperative function of corporate governance to business operation is to lessen agency expenses owing to the close and thorough supervision of management, which can lead to competitive advantages that help the firm to obtain sustainable economic growth.

In developing countries, corporate governance faces various challenges such as low institutional ownership, centered ownership and underdeveloped finance markets ${ }^{5}$; there is therefore a big need to carry out research on this field in those countries including Vietnam. Good corporate governance can improve financial effectiveness ${ }^{6,7}$ and simultaneously facilitate socially responsible activities by organizations $s^{8,9}$. Furthermore, grounded on agency premise, stakeholder view, information asymmetry premise and legitimacy premise $e^{10}$, tried to investigate the impact of firms' socially responsible activities on their financial effectiveness and found out there is a significantly positive effect of the socially responsible activities on the financial effectiveness. Drawing on ${ }^{11}$, there could be an interference of socially responsible activities in the linkage of financial effectiveness with corporate governance.

Additionally ${ }^{3}$, emphasized the significance of establishing research models that amalgamate missing factors, explores intervenient influences and business situations. Numerous studies on the linkage of firm performance with between corporate governance have been conducted. For example ${ }^{5}$, examine the mediation of earnings quality into the relation of firm performance with corporate governance or $^{2}$ explores the moderation of corporate governance between socially responsible activities and financial effectiveness.

However, it seems that, no scholars have examined the causal connection from corporate governance to financial effectiveness systematically by taking the role of socially responsible activities in account. This research is going to study the association among socially responsible activities, financial effectiveness and corporate governance, focusing on the intervention of socially responsible activities. Particularly, this research work was conducted in Vietnam as a developing market, where studies on management practices are still unassuming ${ }^{4}$.

\section{Literature Survey}

Separation of management and ownership could lead the directors of firms to enjoy superior information to their shareholders, which creates asymmetries ${ }^{5}$. The asymmetries offer the directors opportunities to act for their self-interests; good corporate governance is hence necessarily established to control the self-interested actions of opportunistic directors, aimed to mitigate the risks associated with the asymmetric issues ${ }^{12}$. A firm is a separate official organization with the series of contracts that authorize principals to assign agents to run business on the formers' behalf ${ }^{5}$. If both sides of the principal-agent relationship are utility-maximizing people, there will be a good reason to suppose that their benefits are not aligned. The presence of asymmetric issues between the agent and the principal makes that relationship more complicated. Corporate governance structure is applied as an instrument to control and execute the business activities of companies, connected to the complex relationships among directors, shareholders and other stakeholders ${ }^{5}$.

Stewardship theory is employed to explain the complicated relationship between principals and agents anchored in the separation between ownership and management. Stewardship theory is an assumption in which business directors serve as responsible supervisors of the assets that they are in charge of as well as protect the interests of the owners and make good decisions on their behalf. On the contrary, agency theory presumes that the agent and principal are both motivated to raise their private interests. The difference in benefits between the principal and agent could cause losses for the principal because of opportunistic, individualistic and selfinterested behaviours of the agent if there are not useful managerial instruments ${ }^{13}$.

There is hence a need to develop good corporate governance to moderate asymmetric issues between the managers and owners. Good mechanisms of corporate governance can enable firms to lessen interest divergence between the managers and owners by minimizing agency costs, so leading to sustainable competitive advantages, which likely improve financial effectiveness ${ }^{14}$. The aim of corporate governance mechanisms is to make profits and maintain a firm to be sustainably successful, which hence brings wealth to the shareholders. The companies that hold agency perspective separate the chief executive officer and chairman positions into two separate managers with managerial boards consisting mainly of independent directors ${ }^{15}$. That is because, if the chairman and chief executive officer responsibilities are placed under one manager, the firm likely suffers agency costs derived from the executive's pursuit of his self-interest at organizational expenses. 
Conversely ${ }^{\frac{16}{6}}$, stressed that "not every corporation, which mixes the chairperson and chief executive officer duties, is a bad structure of corporate governance and not every corporation, which segregates the chairperson and chiefexecutive officerduties, is a good structure of corporate governance". This researcher added that, the duality is advantageous due to its united managerial mechanism, so improving decision-making, quick adoption of business decisions, which create competitively advantageous achievements leading to improved financial effectiveness. Following this viewpoint, other scholars $\frac{5,8,17,18}{1}$ considered the duality of the chief executive officer and chairman as a good structure of corporate governance. Additionally, firms where most of the managerial board's members are independent executives could counteract asymmetric issues, because the supervisory boards can monitor their self-serving behaviors ${ }^{19}$. This likely lessens the agency issues, resulting in superior financial effectiveness to the firms. Furthermore, independent managers are normally selected according to their exceptional knowledge, qualified degrees, good experience and skill. They are therefore highly qualified to offer better decisions for their business, creating competitive advantages and so improving financial effectiveness.

Moreover ${ }^{4}$, emphasized the original role of outside independent executives on justifying agency expenses and advancing financial effectiveness. A company may suffer bad financial effectiveness, if the managerial boards are not able to monitor underperforming executives. Therefore, good structures of corporate governance ought to be established to enhance the company's financial effectiveness. Furthermore, the ownership of managerial board members can be employed to encourage directors to work in the way in agreement with their shareholders' prosperity; because that encouragement likely leads the directors to run companies' activities in a better way. For example ${ }^{20}$, offer evidence on a statistical effect of the ownership of executive directors on current and subsequent operating performance. Likewise ${ }^{7}$, deem that, if the ownership of executive directors is in a majority, bad business decisions can activate losses borne by these directors, which enable them to pursue interest maximization for the firm, aimed to avoid losses to their shareholders. If the agent and the principal share the same interest, the agency cost can be extremely mitigated. Following this point of view, the ownership of managerial boards is broadly accepted as an important factor in enhancing financial effectiveness $s^{21,22}$.
Though the causal correlation from corporate governance to financial effectiveness was broadly explored, where a good structure of corporate governance likely maximizes financial profitability $\frac{6,7,5}{2}$. In order to analyze the linkage thoroughly ${ }^{8}$, underlined the importance of a missing actor, which is corporate social responsibility. Anchored in stakeholder and agency theories ${ }^{18}$, suggested an influence which corporate governance imposes on socially responsible actions that the firm takes. In addition, grounded in the stakeholder theor $y^{23}$, argued that, community and relevant stakeholders expect the firm to act in a moral way and be socially responsible. Hence, directors ought to act ethically and present such moral actions for stakeholders to perceive it. If an executive loses trustworthiness, then it is not easy to recover. Better mechanisms of corporate governance demand directors to present their tasks and decision-making as more socially responsible actors.

Furthermore ${ }^{24}$, relied on the agency theory, regarding the relationship between corporate governance and socially responsible actions as a relation of shareholders (principals) with directors (agents); whereas ${ }^{\underline{13}}$, applied the stakeholder theory, revealing that, good structures of corporate governance could stimulate the firm to act in more socially responsible ways. On the other hand, other researchers suggested, socially responsible behaviors of firms likely maximize their financial effectiveness 5 55-27. Social responsibility could be applied to enhance shareholders' benefits and with good structures of corporate governance, directors could act in a more ethical way that improves shareholders' prosperity. Examining the causal association between financial effectiveness and social responsibility $\underline{26}$, showed that, there is no significant effect of socially responsible actions of incorporations on financial effectiveness at the $5 \%$ level, but there is a positive influence at the $10 \%$ significance level. Likewise, socially responsible behaviors of firms are referred to as an important indicator for their sustainable development and a vital and positive determinant of financial effectiveness ${ }^{25-27}$.

As above-mentioned, the relationships linking financial effectiveness to corporate governance, social responsibility to corporate governance, and financial effectiveness to social responsibility have been theoretically and empirically investigated. These relationships occur in the way that corporate governance affects social responsibility that in turn determines financial effectiveness that is affected by corporate 
governance. Therefore, drawing on the suggestions of ${ }^{11}$, it could suggest social responsibility may intervene between financial effectiveness and corporate governance. This intervention of social responsibility could be a missing link from the relation of corporate governance with financial effectiveness, which was ignored in previous studies. Overall then, it can posit the following hypotheses:

H1: Good corporate governance improves financial effectiveness

$\mathrm{H} 2$ : Corporate social responsibility interfere between corporate governance and financial effectiveness

\section{Methodology}

\subsection{Variable Measurements}

Corporate governance (CGE) is proxied by managerial independence, ownership concentration and chief executive officer - chairperson duality. Managerial independence (CGE1) refers to the percentage of outside independent managers in the managerial board. Ownership concentration (CGE2) is the percentage of share capital owned by all the directors in the managerial board. Chief executive officer - chairperson duality (CGE3) is a dummy variable recoded one (1) if the chief executive officer and chairperson is a single individual; recoded zero (0) otherwise. These items are adapted from, $, 6,17,20$.

Corporate social responsibility (CRE) is assessed on the dimensions recommended by ${ }^{28}$. There are four (4) variables proxying corporate social responsibility. Firstly is corporate responsibility to the workplace composed of five (5) items (CRW). Secondly is corporate responsibility to the business environment consisting of five (5) items (CRB). Thirdly is corporate responsibility to the natural environment comprising six (6) items (CRN). Finally is corporate responsibility to the community made up of five (5) items (CRC).

Financial effectiveness (FLP) is calculated on Tobin's q ratio that is suggested by ${ }^{3}$. Drawing on ${ }^{\frac{5}{5}}$ Latif et al. (2017), this research calculates Tobin's q ratio on the total asset book value divided the amount of the equity market value and the liabilities book value.

Following ${ }^{3}$, industrial sector, firm size as well as firm risk have been documented as the antecedents of financial effectiveness and social responsibility; so they are suggested as control variables (COV) for this research. Firm size (FSI) is referred to as the logarithm of total assets, because larger firms are believed to spend more on corporate socially responsible activities and gain more financial effectiveness ${ }^{18}$. Firm risk (FRI) is assessed on the firm's beta ${ }^{3}$; while industrial sector (INS) is calculated on a three-point scale adapted from previous studies such $\frac{29,30}{}$.

\subsection{Data Collection and Analyses}

The research population was composed of companies that appeared in Vietnam's major Stock Exchanges. There were 380 companies appeared on the Stock Exchange of Ho Chi Minh, 376 companies listed on Hanoi Stock Exchange and 807 companies registered on Unlisted Public Company Market (UPCoM). Therefore, there were 1,563 companies in total. The questionnaires were offered to 100 firms in HOSE, 100 in HNX and 200 in UPCoM, by the ration of 1:1:2. The targeted companies were selected by using the technique of simple random sampling. Of the 400 delivered questionnaires, only 306 responses provided adequately required information.

\section{Empirical Result and Discussion}

Having collected and cleaned the needed data, reliability analyses were applied to test the reliability for the construct 'corporate social responsibility' that consists of four variables with multiple items. Subsequently, the principal component analysis was employed to calculate the composite scores of the four variables for the factors "corporate social responsibility"; then to average the four scores to make up the overall score of corporate social responsibility. To test the presence of multi-collinearity in the research models, the correlations among the independent variables were computed. The regression analysis was employed to examine the causal hypothesis. The procedures based on ${ }^{1}$ were applied to consider the statistical significance for the interference effect of corporate social responsibility on the causal link from corporate governance structure to corporate financial effectiveness.

To analyze the consistence of measurements that are multiple-dimensioned, it should perform reliability analyses. The construct of corporate social responsibility (CRE) was tested with the procedures of reliability analyses. The analyses were conducted for 'corporate responsibility to the workplace (CRW)' with five (5) items; 'corporate responsibility to the business environment (CRB)' with five (5) items; 'corporate responsibility to the natural environment (CRN)' with six (6) items; and 'corporate responsibility to the community (CRC)' with five (5) items. The first reliability analysis for 
CRN yielded out an inconsistent result. The corrected item-total correlation of CRN6 obtained a value of 0.089 less than 0.5 ; and concurrently the the Cronbach's $\alpha$, if the item deleted is 0.856 greater than 0.778 - the Cronbach's $\alpha$ of the reliability analysis (untabularized). Thereby, CRN6 was taken away from $\mathrm{CRN}^{31}$; as a result, $\mathrm{CRN}$ only still consists of five (5) items. The reliability analyses for the remaining items produced the findings in Table 1 . The empirical results show that the rest 20 items obtain their own total correlations all exceeding the 0.5 threshold ${ }^{31}$. Additionally, the Cronbach's as are larger than the 0.7 lowest value ${ }^{31}$. These findings indicate the 20 items of CRE are internally consistent.

To examine the proposed research hypotheses, this research applied the three (3) following research models:

$$
\begin{gathered}
\mathrm{FLP}=\alpha_{0}+a_{1} \mathrm{CGE}+\varepsilon(\mathrm{MODEL} 1) \\
\mathrm{CRE}=\theta_{0}+\theta_{1} \mathrm{CGE}+\zeta(\mathrm{MODEL} 2) \\
\mathrm{FLP}=\delta_{0}+\delta_{1} \mathrm{CGE}+\delta_{2} \mathrm{CRE}+\xi(\mathrm{MODEL} 3)
\end{gathered}
$$

In the analyzed research models, there are seven (7) independent variables; therefore, the correlation analyses were employed, the results of which are shown in Table 2. The findings indicate the correlations between the pairs of variables are all smaller than 0.8 , the highest value $e^{32}$, indicating the multi-colinearity issues are absent in the research models.

Hypothesis H1 "Good corporate governance improves financial effectiveness" was investigated with the regression analysis that regressed financial effectiveness on corporate governance along with the control variables of firm size; firm risk and industrial sector (see MODEL1).Theempirical results $\left(\mathrm{R}_{\text {-squared }}=0.619 ; \mathrm{F}=81.012\right.$; Sig. $_{\mathrm{f}}=0.000<1 \%$ ) are exhibited in Table 3.

The three (3) items of corporate governance, along with the control variables of firm size, firm risk and industrial sector explain $61.9 \%$ of variation in financial effectiveness with $\mathrm{F}$ of 81.012 at the $1 \%$ significance value. Managerial independence (CGE1) positively influences financial effectiveness, where the $\beta$ is 0.182 at the $1 \%$ significance value; ownership concentration (CGE2)

\begin{tabular}{|c|c|c|c|c|}
\hline Variables & Items & Total correlations & Alpha $(\alpha)$ f item deleted & Alpha $(\alpha)$ \\
\hline \multirow[t]{5}{*}{ CRW } & CRW1 & .686 & .791 & \multirow[t]{5}{*}{.837} \\
\hline & CRW2 & .637 & .806 & \\
\hline & CRW3 & .642 & .809 & \\
\hline & CRW4 & .626 & .810 & \\
\hline & CRW5 & .630 & .808 & \\
\hline \multirow[t]{5}{*}{ CRB } & CRB1 & .812 & .915 & \multirow[t]{5}{*}{.930} \\
\hline & CRB2 & .859 & .906 & \\
\hline & CRB3 & .771 & .923 & \\
\hline & CRB4 & .761 & .925 & \\
\hline & CRB5 & .889 & .901 & \\
\hline \multirow[t]{5}{*}{ CRN } & CRN1 & .676 & .826 & \multirow[t]{5}{*}{.856} \\
\hline & CRN2 & .648 & .832 & \\
\hline & CRN3 & .656 & .830 & \\
\hline & CRN4 & .707 & .817 & \\
\hline & CRN5 & .673 & .827 & \\
\hline \multirow[t]{5}{*}{ CRC } & $\mathrm{CRC1}$ & .747 & .858 & \multirow[t]{5}{*}{.886} \\
\hline & CRC2 & .777 & .852 & \\
\hline & CRC3 & .708 & .866 & \\
\hline & CRC4 & .696 & .868 & \\
\hline & CRC5 & .715 & .866 & \\
\hline
\end{tabular}
is positively related to financial effectiveness with the $\beta$

Table 1. Reliability analyses (CRE)

Source: Researcher own calculations 
Table 2. Spearman correlations

\begin{tabular}{|c|c|c|c|c|c|c|c|}
\hline & CGE1 & CGE2 & CGE3 & FSI & FRI & INS & CRE \\
\hline CGE1 & 1 & & & & & & \\
\hline CGE2 & .664 & 1 & & & & & \\
\hline CGE3 & .328 & .345 & 1 & & & & \\
\hline FSI & .678 & .698 & .317 & 1 & & & \\
\hline FRI & .671 & .687 & .329 & .756 & 1 & & \\
\hline INS & .162 & .164 & .181 & .152 & .139 & 1 & \\
\hline CRE & .545 & .588 & .401 & .591 & .568 & .214 & 1 \\
\hline
\end{tabular}

Source: Researcher own calculations

Table 3. OLS Regression analyses

\begin{tabular}{|c|c|c|c|c|c|c|c|c|c|}
\hline & \multicolumn{3}{|c|}{ FLP (1) } & \multicolumn{3}{|c|}{ CRE (2) } & \multicolumn{3}{|c|}{ FLP (3) } \\
\hline & $\beta$ & $\mathrm{t}$ & Sig. & $\beta$ & $\mathrm{t}$ & Sig. & $\beta$ & $\mathrm{t}$ & Sig. \\
\hline $\mathrm{C}_{0}$ & .252 & 1.206 & .229 & -2.978 & -13.340 & .000 & .636 & 2.427 & .016 \\
\hline \multicolumn{10}{|l|}{$C G E$} \\
\hline CGE1 & .182 & 3.296 & .001 & .110 & 1.862 & .064 & .168 & 3.046 & .003 \\
\hline CGE2 & .149 & 1.917 & .056 & .177 & 2.132 & .034 & .126 & 1.624 & .105 \\
\hline CGE3 & .154 & 2.371 & .018 & .270 & 3.884 & .000 & .120 & 1.807 & .072 \\
\hline \multicolumn{10}{|l|}{ CRE } \\
\hline CRE & & & & & & & .129 & 2.397 & .017 \\
\hline \multicolumn{10}{|l|}{$\mathrm{COV}$} \\
\hline FSI & .351 & 4.103 & .000 & .189 & 2.069 & .039 & .327 & 3.821 & .000 \\
\hline FRI & .190 & 3.224 & .001 & .120 & 1.897 & .059 & .175 & 2.969 & .003 \\
\hline INS & .092 & 2.275 & .024 & .084 & 1.950 & .052 & .081 & 2.010 & .045 \\
\hline $\mathrm{R}_{\text {-squared }}$ & \multicolumn{3}{|c|}{.619} & \multicolumn{3}{|c|}{.448} & \multicolumn{3}{|c|}{.626} \\
\hline $\mathrm{F}$ & \multicolumn{3}{|c|}{81.012} & \multicolumn{3}{|c|}{40.471} & \multicolumn{3}{|c|}{71.362} \\
\hline Sig. $_{f_{f}}$ & \multicolumn{3}{|c|}{$<1 \%$} & \multicolumn{3}{|c|}{$<1 \%$} & \multicolumn{3}{|c|}{$<1 \%$} \\
\hline Durbin-Watson & \multicolumn{3}{|c|}{1.802} & \multicolumn{3}{|c|}{1.885} & \multicolumn{3}{|c|}{1.934} \\
\hline
\end{tabular}

Source: Researcher own calculations

of 0.149 at the $10 \%$ significance level; and chief executive officer - chairperson duality (CGE3) positively affects financial effectiveness with the $\beta$ of 0.154 at the $5 \%$ significance level. Moreover, the Durbin Watson statistic of MODEL 1 is 1.802 around 2, falling between $d_{U}$ to $d_{4-U^{\prime}}$ indicating no autocorrelation in the research model. Those findings are all in support of Hypothesis 1 where "the better corporate governance, the better financial effectiveness the firm gains".

Hypothesis H2 "Corporate social responsibility intervenes on the influence of corporate governance on financial effectiveness" was examined with the procedures, as $\underline{11}$ recommended, where the other two (2) research models were carried out as illustrated in Table 3 (MODEL 2 and MODEL 3). The findings indicate that, Fs of the two models are 40.471 and 71.362 , both of which correspond with the Sig.s less than $1 \%$, demonstrating both the models fit well enough. In addition, Durbin Watson statistics of MODEL 2 and MODEL 3 are 1.885 and 1.934, both of which are around 2, falling between $\mathrm{d}_{\mathrm{U}}$ to $\mathrm{d}_{4-\mathrm{U}}$ indicating the absence of autocorrelation in the research models.

The three components of corporate governance "CGE1, CGE2 and CGE3" influence corporate social responsibility with the coefficients of $0.110,0.177$ and 0.270 at the $10 \%, 5 \%$ and $1 \%$ significance levels respectively 
(MODEL 2). In MODEL 3, managerial independence (CGE1) and chief executive officer - chairperson duality (CGE3) affect financial effectiveness with the estimates of 0.168 and 0.120 at the $1 \%$ and $10 \%$ significance levels. In contrast, ownership concentration (CGE2) has no impact on financial effectiveness, whereas corporate social responsibility influences financial effectiveness with the estimator of 0.129 at the $5 \%$ value of significance.

In the comparison between MODEL 1 and MODEL 3 , the impact of corporate governance "CGE1, CGE2 and CGE3" on financial effectiveness in MODEL 1 decreases from $0.182,0.149$ and 0.154 to $0.168,0.126$ and 0.120 respectively in MODEL 3; whereas $R_{\text {-squared }}$ augments from $0.619 \%$ to 0.626 . Those are in support of Hypothesis 4 for the intervenient function of corporate social responsibility on the causal connection between corporate governance and financial effectiveness; nevertheless, for the robustness, this study carried on with the techniques stipulated by $\frac{1}{1}$ to examine the significance of statistics for the mediation hypothesis. The procedures produced the outcomes exhibited in Table 4. The empirical findings indicate, corporate social responsibility statistically intervene in the impact of corporate governance on financial effectiveness at the 5\% level with the $t_{\text {indirect }} s$ of 2.041,2.126 and 2.031 respectively for CGE1, CGE2 and CGE3. Overall, it can recommend that, corporate social responsibility fully intervenes in the causal association from ownership concentration (CGE2) to financial effectiveness; while it just partially mediate the effects of managerial independence (CGE1) and chief executive officer - chairperson duality (CGE3) on financial effectiveness.

\section{Conclusions}

The current project is to assess the relations among corporate governance, corporate social responsibility and financial effectiveness. It especially focused on the interference function of corporate social responsibility in the causal linkage from corporate governance to financial effectiveness. The empirical findings revealed that, firms, where the chief executive officer and chairperson responsibilities are placed under one individual, enjoy competitive advantages and hence achieve superior financial effectiveness compared to others. This evidence is consistent with the standpoint of some previous researchers $\frac{5,8,16,1,17}{}$. The independent directors in the managerial board play a significant function in making more effective business decisions, consistent with those ${ }^{4,19}$. The ownership of executive directors in managerial boards is statistically evidenced as an essential factor improving financial effectiveness as recommended by $\frac{7,20}{}$. Therefore, it can propose that firm with good corporate governance likely enjoy improved financial effectiveness. In addition, firms where there are good corporate governance structures, will likely act in more socially responsible ways that are supposed to create intangible assets, which can lead to better financial effectiveness.

Corporate social responsibility is statistcally documented as an important mediator in the causal link from corporate governance to financial effectiveness. Corporate social responsibility fully interferes with the effect of ownership concentration in the managerial board on financial effectiveness. In contrast, it just partially mediates the influences of managerial independence and chief executive officer - chairperson duality on financial effectiveness. The empirical findings provide a wider understanding of the complex links among financial effectiveness, corporate social responsibility and corporate governance. It emphasizes the importance of corporate social responsibility on the causal linkage from corporate governance to financial effectiveness, which was ignored in prior research. Firms are supposed to be more socially responsible and to decide on more appropriate corporate governance practices, which could improve financial effectiveness. Corporate social responsibility should be highlighted, because of its role of intervention in transforming the influence of corporate governance through it to financial effectiveness.

Table 4. Intervenient analyses

\begin{tabular}{|c|c|c|c|}
\hline Intervenient Variable & Causal linkage & $\mathbf{t}_{\text {-intervention }}$ & Sig. \\
\hline \multirow{3}{*}{ CRE } & CGE1 on FLP & 2.041 & .041 \\
\cline { 2 - 4 } & CGE2 on FLP & 2.126 & .034 \\
\cline { 2 - 4 } & CGE3 on FLP & 2.031 & .042 \\
\hline
\end{tabular}

Source: Researcher own calculations 


\section{References}

1. Sobel ME. Asymptotic confidence intervals for indirect effects in structural equation models. Sociological Methodology. 1982; 13(1):290-312.

2. Yeon KH. Moderating Effect of Corporate Governance Structure between Corporate Social Responsibility and Performance. Indian Journal of Science and Technology. 2016; 9(46):1-7.

3. Surroca J, Tribo JA, Waddock S. Corporate responsibility and financial performance: The role of intangible resources. Strategic Management Journal. 2010; 31(5):463-90. https:// doi.org/10.1002/smj.820

4. Wang DHM, Huynh QL. Linkages among corporate governance, management accounting practice and organizational performance: Evidence from a Southeast Asian country. Romanian Economic and Business Review. 2014; 9(1):63-81.

5. Latif K, Bhatti AA, Raheman A. Earnings quality: A missing link between corporate governance and firm value. Business and Economic Review. 2017; 9(2):255-80. https:// doi.org/10.22547/BER/9.2.11

6. Sobel ME. Asymptotic confidence intervals for indirect effects in structural equation models. Sociological Methodology. 1982; 13(1):290-312.

7. Chung LH, Wei CC. The Impact Effect of Corporate Governance and Corporate Social Responsibility on Company Performance After the Financial Tsunami. Asian Journal of Economic Modelling. 2017; 5(4):465-79. https:// doi.org/10.18488/journal.8.2017.54.465.479

8. Jo H, Harjoto MA. The causal effect of corporate governance on corporate social responsibility. Journal of Business Ethics. 2012; 106(1):53-72. https://doi.org/10.1007/s10551011-1052-1

9. Chintrakarn P, Jiraporn P, Kim JC, Kim YS. The effect of corporate governance on corporate social responsibility. Asia-Pacific Journal of Financial Studies. 2016; 45(1): 102-23. https://doi.org/10.1111/ajfs.12121

10. Sandaruwan C, Ajward R. The Relationship between Corporate Social Responsibility and Financial Performance: The Effect of Easy Access to Capital and Managerial Ownership. Sri Lankan Journal of Management. 2017; 22(2):73-105.

11. Baron R, Kenny D. The moderator-mediator variable distinction in social psychological research: conceptual, strategic and statistical considerations. Journal of Personality and Social Psychology. 1986; 51(6):1173-8. https://doi. org/10.1037/0022-3514.51.6.1173 PMid:3806354

12. Akileng G. The efficacy of corporate governance in reducing opportunistic accounting earnings manipulations. Management. 2014; 5(24):44-69.
13. Davis JH, Schoorman FD, Donaldson R. Toward a stewardship theory of management. Academy of Management Review. 1997; 22(1):20-47. https://doi.org/10.2307/259223 https://doi.org/10.5465/amr.1997.9707180258

14. Cadbury Report. Available from: https://en.wikipedia.org/ wiki/Cadbury_Report. Date accessed: 28/01/2019.

15. Wang DHM, Huynh QL. The Role of Corporate Governance in the Link between Management Accounting System and Firm Performance. Asian Journal of Finance \& Accounting. 2014; 6(1):216-35. https://doi.org/10.5296/ajfa.v6i1.5159

16. Vo TNT. To Be or Not to Be Both CEO and Board Chair. Brooklyn Law Review. 2010; 76(1):65-129.

17. Dias A, Rodrigues LL, Craig R. Corporate Governance Effects on Social Responsibility Disclosures. Australasian Accounting. 2017; 11(2):3-22. https://doi.org/10.14453/ aabfj.v11i2.2

18. Relationship between Corporate Governance and Corporate Social Responsibility Disclosure in Brazilian Companies. Available from: https://www.semanticscholar. org/paper/RELATIONSHIP-BETWEEN-CORPORATEGOVERNANCE-AND-IN-de-Araujo/409ab92722d53f98a edf356bcf25e82dec734350. Date accessed: 2016.

19. Huynh QL. Insight into the Links among External Business Environments, Corporate Governance and Organizational Performance. Asian Journal of Finance \& Accounting. 2018; 10(1):115-30. https://doi.org/10.5296/ajfa.v10i1.12655

20. Bhagat $S$, Bolton B. Corporate governance and firm performance. Journal of Corporate Finance. 2008; 14(3):257-73. https://doi.org/10.1016/j.jcorpfin.2008.03.006

21. Chung KH, Pruitt SW. Executive ownership, corporate value, and executive compensation: A unifying framework. Journal of Banking and Finance. 1996; 20(7):1135-59. https://doi.org/10.1016/0378-4266(95)00039-9

22. Jensen MC, Murphy KJ. Performance Pay and TopManagement Incentives. Journal of Political Economy. 1990; 98(2):225-64. https://doi.org/10.1086/261677

23. Carroll AB. Corporate social responsibility. Business and Society. 1999; 38(3):268-95. https://doi.org/10.1177/ 000765039903800303

24. Barnea A, Rubin A. Corporate social responsibility as a conflict between shareholders. Journal of Business Ethics. 2008; 97(1):71-86. https://doi.org/10.1007/s10551-0100496-z

25. Oh S, Hong A, Hwang J. An Analysis of CSR on Firm Financial Performance in Stakeholder Perspectives. Sustainability. 2017; 9(6):1-12. https://doi.org/10.3390/ su9061023

26. Arshad MG, Anees F, Ullah MR. The impact of corporate social responsibility on firm's financial performance. International Journal of Linguistics, Social and Natural Sciences. 2015; 1(1):33-9. 
27. Jallo A, Mus AR, Mursalim, Suryanti. Effect of corporate social responsibility, good corporate governance and ownership structure on financial performance and firm value: A Study in Jakarta Islamic Index. IOSR Journal of Business and Management. 2017; 19(11):64-75.

28. Mai NP. Corporate social responsibility in Vietnam textile and garment industry - Case of May Cau Cau Joint Stock Company. Vietnam National University Journal of Science: Economics and Business. 2009; 29(1):32-40.

29. Brouthers KD, Brouthers LE, Werner S. Industrial sector, perceived environmental uncertainty and entry mode strategy. Journal of Business Research. 2002; 55(6):495-507. https://doi.org/10.1016/S0148-2963(00)00154-5
30. Taha A, Etemadi H, Pifeh A. Exploration of Factors Influencing on Choice the Activity-Based Costing System in Iranian Organizations. International Journal of Business Administration. 2011; 2(1):61-70.

31. Multivariate Data Analysis. Available from: https:// en.wikipedia.org/wiki/Multivariate_analysis.Dateaccessed: 15/02/2019

32. A Guide to Econometrics. Available from: https://www. wiley.com/en-us/A+Guide+to+Econometrics\%2C+6th+ Edition-p-9781405182577. Date accessed: 1992. 